\title{
Restructuring Integrated Watershed Management Models for the Federal Democratic Regime of Nepal
}

\author{
Shambhu Paudel ${ }^{1,2 *}$, Prabhat Pal ${ }^{3}$ and Harish Singh Dhami ${ }^{4}$ \\ ${ }^{1}$ Institute of Forestry, Tribhuvan University, Pokhara, Nepal \\ ${ }^{2}$ Ph.D Student, School of Natural Resources and the Environment, The University of Arizona, \\ Tucson, USA ${ }^{3}$ Ministry of Forests and Environment, Nepal, \\ ${ }^{4}$ Freelancer, based in Kathmandu. \\ ${ }^{*}$ Corresponding author:: spaudel@iofpc.edu.np
}

\section{Abstract}

Recent political envision has redesigned the administrative units of Nepal into federal states with the aim of decentralizing the power to ensure the process of rapid sustainable development. As a consequence, all the public service agencies need to restructure their delivery units for achieving goals targeted by the newly adopted administrative regime plan. With the aim of recommending the best watershed management models for this changing context, this paper aims to review existing watershed management models applied in different continents like European union, African union and the United States where they have already adopted this watershed management plans into their federal states or countries union successfully. Although they are geographically distinct and economically advanced, the major approach adopted is a river basin approach with the clear legislative framework. This approach is highly succeeded between interstate (or between member countries) because of political or interstate commitments for the common pool resource water. Clear policies and commitments between member countries or interstate greatly improved the function of this mechanism. With the light of those experiences in the field of watershed management plan adopted in federal or union countries, river based integrated management plan balancing efforts between interstates seems best models in the world, and is also proposed for the new federal republic of Nepal.

Key words: Fuderal, Policy, Water sustainable developmenmt, Common pool resource.

\section{Introduction}

Nepal went through a long political impasse before the present federal system was implemented. And now it is a challenge for the approach to be efficient and receptive to the demands of the Nepalese people. The present scenario of increasing water induced disaster in various parts of the country reveals that climate change has resulted in havoc in the country. Simultaneously, various coping strategies have been sought through various field level interventions, appropriate policy instrument, and timely organizational structure. A discourse has been going in every nook and corner upon appropriate and effective service delivery model with the advent of the present constitution which has envisioned the devolution of rights and accountability to local levels through three forms of government: central, federal or provincial and local, considering sovereignty of local people; the important outcome of changing scenario. This endeavor requires formation of a suitable organizational structure which must comply with the present constitution. At present there are several organizations like District Forest Office, District Agriculture Office, District Veterinary Office, District Health Office, etc. which deliver their services to locals through Range, Sector and Service centers but on the contrary, organizations like 
District Soil Conservation Office, District Administration Office, Division of Water Induced Disaster Prevention, Division of Roads provide their services through district offices and their respective divisions till date. So, these organizations demand new organizational setup matching with the federal and local government to mark their presence at the local level. This paper explores structures and models for restructuring the soil conservation and watershed management activities through civil service in Nepal, taking into account the existing context of public administration and civil service management. It explores the possible watersheds management models with references to lessons learned from different continents of the world.

\section{Materials and methods}

The following methodology was adopted.

a) All relevant studies and reports prepared by the Government of Nepal and I/ NGOs were identified. These included restructuring plan of Forest and Soil Ministry, and international watershed program plans and working strategies adopted by internationally recognized agencies. On the basis of these reports, including the reports of the commissions, were also studied and in view of the enormity of the task, maximum possible information was deemed able to provide the most useful recommendations. Reviews of the existing civil services in Nepal, including the proposals of the administrative reform commissions, were also assessed.

b) Review of the best practices and lessons learned from other countries or union with similar experience (federalization) were carried out from some few nations or continents, keeping the lessons as compatible to the Nepalese context as possible. Of course, no two countries are similar and hence it was not easy to draw lessons that will suit exactly the present scenario and challenges of Nepal.

c) Inferences were drawn from discussions and interactions during District Soil Conservation Officers Workshop with pertinent stakeholders, Department level and Ministry level consultation. These platforms were extensively used to identify needs, understand the situation, and finally conclude viable options for structuring and reforming organizations in the context of federalisation.

d) On the basis of the analysis, review and deductions, the paper was finalized for options and strategies recommended for consideration.

\section{Results and Discussion Case Studies}

\section{Models in the Europe}

Watershed management in Europe focused on the river basin approach using transboundary initiates with a clear legal framework where all the member countries agreed upon common goals (Zingari, 2002).

A Clear example of this is the EU Water Framework Directive (WFD), which was established under a clear legal framework to protect and enhance the status of aquatic ecosystems, prevent their deterioration and ensure long-term, sustainable use of water resources (Krecek, 2005; GWP, 2015). The Directive provides for an innovative approach to water management based on river basins, the natural geographical and 
hydrological units, and sets 30 years as a deadline for the EU Member States. It establishes several integrative principles for water management, including public participation in planning and the integration of economic approaches, and also aims for the integration of water management into other policy areas. Initially, very narrow specific conservation approach was started for watershed conservation, where mountain region was managed through Torrent Control and Protection from Avalanches. Afterwards, in 1998, the theme of the twenty-first session of the working party, held in Marienbad, Czech Republic, realized the importance of integrated management of mountain watersheds, discussing a modern watershed concept using the procedure of both the environmental impact assessment (EIA) and strategic environmental assessment (SEA). The working party's main aim is to support sustainable sound development in European mountain regions through interdisciplinary networking of government representatives (EFC member countries) and observers (representatives of NGOs, developing countries or the individuals involved). Recently, the socioeconomic changes in mountain regions in Europe (losing local farmers and growing mass tourism) with new safety demands focused on prediction and prevention, global climate change or global pollution problems (air pollution, toxic rain impacts, degradation of natural resources) moved the working party to the integrated concept of watershed control, based on integrated ecological monitoring, environmental impact assessment and broad participatory processes. Dealing with all problems in European mountainous region, a working group of Europe recognized the concept of watershed management to be an effective tool to control mountainous landscape.

After 1990s, European countries were mainly focused on catchment management and Trans Boundary River. International cooperation started in many catchments, and large trans-boundary catchment projects were established, such as Danube river basin, Rhine river basin, Elbe, Oder. Danube river basin, which covers 19 European countries occupying the total area $8,01,463 \mathrm{~km} 2$, is the second largest river basin. The ecosystems of the Danube River Basin - and, by extension, the Black Sea, into which the Danube drains - are highly valuable in environmental, economic, historical and social terms. Recognizing the increasing pressure and pollution from agriculture, industries and cities and managing large region while meeting the need of 81 million people, the riparian countries of the Danube basin agreed to manage the watershed cooperatively. The International Commission for the Protection of the Danube River (ICPDR) was established in 1998 to implement the Danube River Protection Convention. Convention had created a different goal in the river basin. The success of river based watershed management in European countries is the establishment of effective mechanisms for cooperation. Key elements of this mechanism are currently in action and are now in place: a legal framework for cooperation, a functioning commission, and political commitment from all the countries. The WFD requires all EU surface inland, transitional and coastal waters, and groundwater's to reach 'good status' or 'good ecological potential' by 2015 . 
This is achieved by meeting demanding environmental objectives, especially ecological and chemical targets. Jointly all the member countries measure its outcomes toward the achievement of good status. In this way, qualitative and quantitative issues were addressed for trans-boundary ground water. In addition, they are working on sediment management and invasive

\section{Models in the USA}

All the 50 states of the USA have adopted riverbasinapproachforbuildingpartnerships among them to better achieve shared water resource management goals and objectives. The management framework is designed to make coordination easier and effective. To assist this process and goals, mostly used interstate management approach is the rotating basin approach. In this approach, watersheds in a state are grouped into basin management units consisting of discrete bundles of watersheds and sub watersheds. After geographic management units are designated, states have adopted a fivestep watershed management process to focus process activities within each basin while staggering the overall workload statewide. Under this framework, watershed assessment, planning, and management activities are grouped into five general categories: (1) Data Collection/ Monitoring, (2) Assessment/Prioritization, (3) Strategy Development, (4) Basin Plan Review/Approval and (5) Implementation (USEPA, 2002). This framework includes the supporting structure for coordinating efforts or integrating core program, operating procedure, time lines, and a way to communicate. They had undertaken numerous efforts to assist states in adopting watershed management approach by alien species in order to improve the data base. The most substantial progress on the ground occurs at smaller scales and, these countries agreed on a system of close transboundary co-operation, aiming to achieve integrated management of the River Basin (Tennyson,2002).

providing technical assistance, publishing communication and outreach materials, and offering facilitation and training. The state wide watershed approach consists of five key components, which include delineation of a state into natural geographic (e.g., watershed/basin)managementareas; actions within geographic areas (i.e., monitoring, assessment, planning, implementation); and a focus on environmental results rather than only program measures. The trend in the statewide watershed management approach appears to be a more localized, partnership-based approach driven by multi-stakeholder teams. North Carolina, an initial program in Texas, Washington and Ohio, where the watershed program was developed earlier tended to focus mostly on developing and better coordinating federally delegated clean water act program on a basin-wide level. Meanwhile new and the older program had added significant opportunities for public input and involvement (Cao, 2006).

\section{Models in the Africa}

Countries like Ethiopia, Kenya, Rwanda, Sudan, and Uganda have developed Integrated Water Resources Management (IWRM) strategies for ensuring environmental sustainability. Many African and sub-Saharan countries face severe 
challenges in securing sustainable and sufficient access to quality water to meet increasing demands of growing population and socio economic development. With all these, it is essential to preserve the ecosystem on which water resource depends. Many sub-Saharan countries are in the condition of water stressed and need to be sustainably managed for the increasing population demand. The Global Water Partnership Eastern Africa (GWP EnA) was launched in 2003 as a multistakeholder platform to increase IWRM knowledge sharing, dialogue, networking, and communication as key drivers for strengthening stakeholder engagement in formulating policy and implementing water sector development plan. Development of partnership forum clearly indicates the promotion of integrated watershed management plan. For instance, the water ministers of the Nile Basin countries had assembled officially in 1998 to form Nile Basin Initiative (NBI), which was the first step toward adopting IWRM principles in the Africa continent. Under this initiative, all riparian countries in the Nile Basin initiated water legislation revision and passed policy, act, regulation, and master plan based on IWRM principles. Although the process of adopting and putting IWRM into practice varies from country to country and reflects the different approaches to natural resources management and governance, there are some common threads, which include: enhancing coordination among sectors and in most countries, adopting a basin approach, establishing a legal framework for IWRM and introducing regulations for trans-boundary water bodies. With the light of this vision, they have adopted "Africa's shared Water Vision 2025 “. In Ethiopia, the watershed is managed by river basin organization which comprises basin high council and river basin authorities. Berki Watershed in the highlands of Tigray, which flows to join the Giba River, a tributary of the River Tekeze, which ultimately joins the Nile which covers about 410 $\mathrm{km} 2$ covering 3 districts, is one of the major watersheds, where integrated water resource management approach is adopted (Kidanemaraim, 2009). Water is the main source of conflict in this watershed. It lacks an institutional framework and there is little understanding of an IWRM approach. Realizing these problems and the potential solutions provided by an IWRM approach, GWP Ethiopia established a pilot activity in the Berki Watershed with the potential for further scaling up. The process involved multi-stakeholder participatory planning within the watershed.

Kenya is currently going through a process to decentralize government structures and responsibilities to county governments. This has a direct impact on the water services sector as well as the already decentralized (based on river basins and watersheds) system. New (regional or local) demands from the county governments have a direct impact on implementation at basin and catchment levels. The Kenyan water sector reforms enacted in 2002 provide a good example of putting the principles of IWRM into practice. IWRM represents a move away from the traditional ministerial top-down approach to water management towards a holistic management approach to both water resources management and water services provision using participatory approaches. 
Among different African countries, different countries have set an enabling environment to put IWRM into practice. That includes a set of rules and regulations that determine the intentions and actions needed to sufficiently assure the sustainable supply of water resources to enable economic and social development. A survey conducted by UN-Water (2008) reported some progress in East Africa

\section{The Proposed Model for Federal Nepal}

Knowing the necessity and importance of soil and watershed management for the local community, the government has proposed sub-basin approach through 23 offices in all the provenience under "Science, Environment and Watershed Division" for integrated management of the watershed (Poudyal, 2017). Forest policy 2015 also incorporates basin approach for watershed management; however, there was poor enforcement of this policy previously. In current situation, Nepal has adopted a federal system which was passed by our constitution in 2016 and has dreamed of three level government- central federal government, state government and local government. Nepalese constitution has proposed an intuitional framework for the conservation of land and water of the country, where Ministry of Forest, Soil Conservation and Environment is at central level. There could be regional offices under this ministry depending upon the coverage and the government type while implementing this model. with regards to the stages of planning and implementing the IWRM concept and introducing management instruments. The UN survey showed that most countries have developed policies, legislation, and institutional arrangements that incorporate an integrated approach, but in Eastern Africa water infrastructure development is still lagging behind (Kidanemaraim, 2009).

Again the Government is focusing on the management strategies adopting older version, where administrative boundary will play a vital role in designing management approach. Regardless of administrative boundaries in several African, European and American countries, clear legislative policy and their commitments have been made instrumental factors for the successful conservation of watershed in integrated approach. With reference to international communities, there is no doubt that focusing on major river systems like Gandaki, Sapta Koshi, Karnali as a basis of management, instead of status quo administrative management strategy, could assist in achieving the envisioned goals of this management. Otherwise, it could be meaningless and can't address the issue of sustainability in future.

At present, the organization is delivering its service through 61 district level offices (DSCOs), which is inadequate regarding its coverage over the nation, scale of impact created through site specific interventions, hydrological issues, etc., which can be addressed through implementation of subbasin approach which attempts to deliver the services through 23 local units in 77 
districts. This approach promotes the coordinated and integrated development of all elements in the watershed to maximize the benefits by maintaining a balance among the environment, economic and social value in an equitable manner without bargaining for sustainability of present ecosystems (National Water Plan, 2002).

According to recent debate and advancement, the placement of Ministry of Forest, Soil and Environment at the central level is almost sure. Similarly, one central department (for example, Department of Forest, Watershed and Environment Management or Department of Soil, Environment Conservation and Forest Management) should be setup combining the entire related sectors like forest, environment, and soil for timely service delivery related to forest management, environment conservation, climate change, natural hazard prevention and disaster management.

Similarly, it would be wise for the placement of Department or Directorate of Watershed and Environment Management at a federal or provincial level for the sensible management of natural resources and environment conservation at the watershed level. In addition, following the concept of river basin, four basin divisions Koshi, Gandaki or Narayani, Karnali and Mahakali under the central government would be viable and scientific for the management of watershed resources. Several models reviewed documents that success of river basin rather than other models in the world. The basin approach has already been in discussion since a decade and noted in
Forest Policy, 2071 and 14th plan (FY 2073/74-2075/76) of Government of Nepal; however, no significant realization and its implementation bas been undertaken until now.

\section{Conclusion}

While targeting poverty reduction through empowerment of rural people to manage their natural resources independently, the integrated watershed management based on minimum ecological flow of main stream at the community levels with linkages to local and state governments will become more viable. Different case studies have shown that integrated watershed management approach focusing on major river basins as a central part of the management systems seems more functional in terms of hydrological and ecological balance if interstates are committed to their defined rules and regulation. Previous white documents of Nepal Government adopted the river basin approach but the poorly developed mechanism and unstable political situation failed to implement that model at the field scales. Therefore, river basin approach can be implemented with the clear legislative framework by involving all the states through which river passed if all the stakeholders can make promises for the common integrated watershed goal.

\section{Acknowledgement}

Thanks to anonymous reviewers and the publication team for your initial comments to improve the quality of manuscript. 


\section{References}

Achouri, M. 2002. Preparing for the next generation of watershed management programs and projects. In: M. Achouri, L. Tennyson, K. Upadhaya and $R$. White (Eds.). Preparing the next generation of watershed management programmes (pp 14-25), FAO, Italy.

Cao, Y.S. and Warford, J. 2006. Evolution of Integrated Approaches to Water Resource Management in Europe and the United States Some Lessons from Experience. Background Paper, (2), pp.1-39.

GWP, 2015. Integrated Water Resource Management in Eastern Africa. Global Water Partnerships, UK.

International commission for the protection of the Dunube River. 2015. The Dunube river basin district management plan, viewed on 10 September 2017,https://www.icpdr. org/flowpaper/viewer/default/files/ nodes/documents/drbmp-update 2015. $p d f$

Kidanemaraim, J. 2009. Participatory integrated water resources management (IWRM) planning: lessons from Berki Catchment, Ethiopia. In Water, sanitation and hygiene: sustainable development and multisectoral approaches. Proceedings of the 34th WEDC International Conference, United Nations Conference Centre, Addis Ababa, Ethiopia, 18-22 May 2009 (pp. 326-333). Water, Engineering and Development Centre (WEDC) Loughborough University of Technology.

Krecek, J. 2005. Overview on the achievements and perspectives of the european forestry commission/FAO working party. Watershed Management and Sustainable Mountain Development. Working Paper (FAO).
National Water Plan. 2002. His Majesty's Government of Nepal Water and Energy Commission Water and Energy Commission Secretariat Singh Durbar, Kathmandu, Nepal.

Poudyal, D. 2074. Report on "Forest, Science and Environmental Ministry Structure in Federal State”. Ministry of Forest and Soil Conservation, Kathmandu, Nepal (Nepali Version).

Tennyson, L. 2002. Review and assessment of watershed management strategies and approaches. In: M. Achouri, L. Tennyson, K. Upadhaya and $R$. White (Eds.). Preparing the next generation of watershed management programmes (pp 19-39), FAO, Italy.

U.S Environmental Protection Agency (USEPA), Office of Water. 2002. A review of Statewide Watershed Management Approaches. USEPA,USA

Zingari, P.C. 2002. Effective watershed management: a European perspective. In: $M$. Achouri, L. Tennyson, K. Upadhaya and $R$. White (Eds.). Preparing the next generation of watershed management programmes (pp 49-53), FAO, Italy. 